\title{
The Turkish History of Special Education from the Ottoman Period to the Present Day
}

\section{Mehmet Emin Öztürk ${ }^{1}$}

Erciyes University

\section{Abstract}

Submitted

Special education has a long history in Western and developing countries. However, literature rarely mentions special education in Turkey, therefore, there are questions about the historical milestones in the Turkish history of special education. The purpose of this paper is to educate the reader about how the treatment and education of people with disabilities in Turkey has evolved throughout history. This literature review will show that Turkey has a long history of providing adaptive education to people with disabilities and gifted and talented students. Innovative practices such as music therapy, herbal medicine, hospitals and Enderun Schools for gifted students were employed in Turkey. This paper specifically focuses on the history of special education in Turkey from the Ottoman period to the present day.

07 November 2019

Revised

24 December 2019

Accepted

25 December 2019

Keywords:

Special Education,

History,

Enderun,

Turkey.

\section{Suggested Citation:}

Öztürk, M.E. (2019). The Turkish history of special education from the Ottoman Period to the present day. International Journal of Academic Research in Education, 5(1), 25-30. DOI: 10.17985/ijare.643995

\footnotetext{
${ }^{1}$ Mehmet Emin Öztürk, Erciyes University, memozturk@erciyes.edu.tr
} 


\section{INTRODUCTION}

Turkey is a unitary, parliamentary, constitutional, republic located at the intersection of Asia and Europe, a meeting point of European, Asian and Middle Eastern cultures. The total population of Turkey is $82,003,882$ and the annual population growth rate is $1.2 \%$ (TUIK, 2018). The population of people with disabilities is $12.29 \%$ of the whole population (Ministry of Family and Social Policies, 2018). The disability population of females (57.2\%) is currently more than males (42.8\%). In 2019, government spending for education was $11.84 \%$ of the total government annual spending (TUIK, 2019).

Turkey adopted the United Nations (UN) Convention on the Rights of Persons with Disabilities in May 2009. Problems related to people with disabilities in Turkey are regulated by the Ministry of Family and Social Policies. The education of people with disabilities is provided by the Ministry of National Education. In Turkey, special education is considered necessary for children up to the age of 18 who show some differences in their physical, mental, psychological, emotional or social characteristics and cannot benefit from the general education services alone (Eres, 2010).

Understanding the history of special education in Turkey will help us to understand the current situation of special education, therefore this review of the literature fills the gap about how history shapes the laws of special education in Turkey. More specifically, the purpose of this literature review is to investigate, synthesize and interpret the history of special education in Turkey. This review of the literature on the history of special education in Turkey and Ottoman Empire explores the following research question:

In what ways does the research literature describe and characterize the history of special education in Turkey and the Ottoman Empire?

\section{Inclusion and Search Criteria}

The search criteria employed for the review attended to: (a) types of publication, (b) years of publication (1997-2019) and (c) peer reviewed articles published in scholarly journals. I chose articles published between 1997 and 2019 because there were some important changes in the special education law in 1997. All sources were peer-reviewed articles published in scholarly journals and books. A total 28 references were originally retrieved to which the following inclusion criteria were applied: (a) the study sample included history of special education; (b) special education laws in Turkey; (c) articles were research studies and published in peer-reviewed journals or books; and $(d)$ the studies were published between 1997 and 2019. I reduced references to 14 using the preceding inclusion and exclusion criteria. Scrutiny of these papers' reference sections led to a further seven papers being identified, giving a total of 21. I eliminated a number of these studies which were not related to special education. As a result, I found a total of 15 journal articles and 3 books and 1 dissertation related to my topic.

\section{History of Special Education in the Ottoman Era}

The Republic of Turkey was established in October 29, 1923. Before the establishment of modern Turkey, it was part of the Ottoman Empire (1299-1923). There were some important milestones related to the history of special education in Turkey during the Ottoman years. One of them was the founding of the Enderun School for gifted and talented students. The school of Enderun was founded in 1455 for gifted and talented students (Corlu, Burlbaw, Capraro, Corlu, \& Han 2010; Melekoglu, Cakiroglu, \& Malmgren, 2009; Sabancı, Bulut \& Daglioglu, 2017, Eris, Seyfi, \& Hanoz, 2008; Senel, 1998; Sirin, Kulaksizoglu, \& Bilgili, 2004).

In the Enderun School, people were educated based on their skills and talents and graduates of the Enderun school took an important role in the governance of the country. Senel (1998) asserts "the purpose of the Enderun School system had been to educate young, gifted people to become administrators, scientists and artists" (p. 255). These people enrolled in the school could be promoted to a 
position which is equal to vice president of the country, based on their success throughout the program. Khervat Mahmud Pasha, Lutfi Pasha, Ibrahim Pasha, Soqullu Muhammad Pasha, Koprulu Muhammad Pasha, Damad Ibrahim Pasha are examples of people who were educated in this school (Tuzder, 2019). In addition, Corlu, Burlbaw, Capraro, Corlu, and Han (2010) argue "Enderun School was an institution that contributed to the rise and staying power of the Ottoman Empire, and a factor in the staying power of the Empire, which survived for more than four centuries after the conquest of Constantinople in 1453" (p. 20). Therefore, they insisted on an investigation of how the system used in that particular school and how it may help the contemporary education system for people who are gifted and talented (Corlu, Burlbaw, Capraro, Corlu, \& Han 2010; Melekoglu, Cakiroglu, \& Malmgren, 2009).

There were many criteria to be eligible for receiving education in Enderun School. The criteria for determining a gifted status included a well-built body, beauty, practical intelligent skills, a strong family bond, etc. These criteria have some similarities with the features of gifted people in recent studies (Sirin, Kulaksizoglu, \& Bilgili, 2004). Nowadays, although these features are not being used as criteria, they are common in people who are gifted. Moreover, individualized education programs (IEP) were used due to the philosophy which states each individual is different (Sirin, Kulaksizoglu, \& Bilgili, 2004). Enderun School was the first school in which gifted students received systematic education in the history of gifted education. Monitoring students and continuity of their personal development based on their skills were essential in this systematic education (Tuzder, 2019).

While providing high quality education in Enderun school for students who were gifted in the Ottoman Empire, people with disabilities were not forgotten. Hospitals were built for treatment of people with disabilities, such as Nureddin Hastahanesi, Fatih Darüşşifası, Edirne Darüşşifası (II. Bayezid Külliyesi), and Gevher Nesibe Sifahanesi. In these hospitals, "music has been used in order to soothe and treat people besides making them relax, feel different emotions, entertain and melancholy" (Sengul, 2008. p. iii or 4). Turkish scholars, Ibni Sina and Farabi claimed that the music is the best way to increase the emotional state of people while treating them (Sengul, 2008; Sezer, 2011; Erer \& Atici, 2010). Using music for treating people with disabilities was such an innovative way in the $15^{\text {th }}$ century.

For implementing the music treatment, sound therapy was used in many hospitals included Edirne Sultan II Beyazit Darussifasi. One of the famous explorers Evliya Celebi (1611-1682) who traveled all of the Ottoman Empire, visited these hospitals. In the Evliya Celebi's notes, using the sound therapy explained as, there was a group of ten young boys who played special instruments, such as violin, panpipe, ceng, lute, flute, and dulcimer, for the patients (Sengul, 2008; Erer \& Atici, 2010). According to Sengul (2008), the hospital provided the pinnacle for treatment of people with disabilities; in addition to music, water-sound was introduced to increase the effectiveness of treatment. Furthermore, the notes stated that not only music was used for people with any kind illness and/or disabilities, but also fragrance was used (Erer \& Atici, 2010). They believed aromatherapy had an impact on people's health and emotions. Daffodil, swan neck, jasmine, gillyflower, caryophyllids, basil, tulips, and lilium were used in the therapy. In the most of the Ottomans' hospitals, music and fragrance treatments for people with disabilities were continued until the end of the $19^{\text {th }}$ century.

For the first time in Turkish history, special education became formalized with the opening of a school in Istanbul by the Director of Commerce in 1889 (Akçamete, 1998). This school was established for deaf students and later for blind students. However, the school was closed in 1919 due to the Ottoman Empire losing World War I therefore funds for education could not be provided (Akçamete, 1998). Another major milestone for special education was the establishment of the school for children with hearing impairments by an Austrian named Monsieur Grati (Grati Efendi). He applied to the Ministry of Education for consent to open a special school. The ministry sanctioned his request; the school opened during the 1891-1892 academic school year (Gok, 1954 as cited in Girgin, 2006). 
In addition, during the Ottoman era, people with special needs were taken care of in the nursing homes along with elderly people. Moreover, some of them were employed in the areas where they could be useful (Sahbaz, 2018).

In the early $20^{\text {th }}$ century major changes happened in the Ottoman Empire. Therefore, nothing really happened related to special education in those years. The Ottoman Empire joined World War I, siding with Germany and Austria-Hungary. After this war, most of the lands of the Ottoman Empire were occupied, and the empire almost collapsed. In order to regain the lands, the Turkish War of Independence (1919-1923) was fought and won.

\section{History of Special Education in the Republic of Turkey}

The Republic of Turkey was established in October 29, 1923. Due to tumultuous times, the only important event about special education during wartime was the opening of the private Izmir Deaf-Blind School in 1921. Between the years of 1924-1950, the school was under the management of the Ministry of Health and Social Aid. After 1950, this school came under the management of the Ministry of National Education. This was an important development for Turkey because it showed that the government accepted that special education was not only related to health, but it also should be part of the formal education (Melekoglu, Cakiroglu \& Malmgren, 2009).

Furthermore, Altinokta Korler Dernegi (The Association Six Points for the Blind), the first blind union in Turkey, was established in 1950. The aim of the organization was "...to develop solutions to economic, social, educational, cultural and occupational problems of people who are visually impaired" (Subasioglu, 2001, p. 367). Also, in the same year, the Mitat Enc Basic Educational School for Children with Visual Impairments was founded, which was the first school for people with visual impairments (Subasioglu, 2001). Shortly thereafter, in 1951, special education came under the supervision of the Department of Elementary Education in the Ministry of National Education.

When the Ministry of National Education took over special education in 1951, they realized that there were no professionally trained personnel to teach the students with special needs. Therefore, the first special education department and teacher training program was created in Gazi University, Ankara in 1952. However, the program ended after two years but was reestablished thirty-five years later in 1987 (Melekoglu et al., 2009). Even though it was initially unsuccessful, it was still a significant step in the history of Turkish special education (Girgin, 2006). In 1965, Ankara University also established special education as a 4-year degree program. They opened masters and doctorate programs during the following years.

"Rehberlik ve Araştırma Merkezi" (RAM) or, in English, the Guidance and Research Center was established as a part of Turkish educational policy in 1955. The Guidance and Research Centers (RAM) are institutions which are affiliated with the Ministry of National Education and can give free support for families of children with special needs in terms of guidance and psychological counseling. The Guidance and Research Center is an indirect and supportive institution that helps schools with guiding and managing behaviours of children. One of the purposes of this center is to diagnose children with disabilities (Melekoglu et al., 2009).

From 1951 to 1980 special education was under the Elementary Education department, but in 1980 the General Directorate of Special Education was established. Finally, in 1983, special education had its own department called Department of Special Education, Guidance and Counseling Services under the Ministry of National Education (Akçamete, 1998).

\section{Special Education Laws in Turkey}

Special Education was mentioned in the constitution for the first time in 1962 in the Primary Instruction and Education Law in Article 12 (No. 222). This law guaranteed that students should have a 
right to education based on their educational needs (Senel, 1998). However, this law did not exactly talked about students with special needs.

In 1971, employment opportunities were guaranteed to people with disabilities for the first time by law in Article 50 number 1475. According to this law, employers who have 50 or more workers have to hire minimum 3\% of their employees from people with disabilities (Melekoglu et al., 2009).

Moreover, the most significant laws in the Constitution of Republic of Turkey related to special education were established in October 9, 1982. These articles are Articles 42, 50, 61 and 70 (Senel, 1998). Translated into English they read as follows:

Article 42 states that: 'for persons who need special education because of their situation, the state undertakes measures in order to make them useful for the society.' Article 50 of the Constitution states that the young, women and individuals with mental and physical disabilities must be protected within work environments. Article 61 of the Constitution requires that the state takes measures in relation to the protection and adaptation of those individuals with disabilities in the society. Article 70 of the Constitution further requires that each citizen of the country has an equal chance to become a public employee (p. 256).

For the first time, teacher training for special education in Turkey was offered in 1983 at Anadolu University (Cavkaytar, 2006). Initially, it started as a graduate program but later it transformed to a four-year undergraduate program.

The 1990s was a foremost decade for special education because of the reauthorization of laws related to special education. The year 1997 was a key year for special education because a new decree having force of law (No. 573) was adopted from United States and England, with new terms such as inclusion, parent involvement in the educational provisions, early intervention, and Individualized Education Programs (IEP). (Akçamete, 2016). Akkok (2010) stated "With this act, bureaucracy, rules, and regulations for special education in Turkey seemed to be at very similar levels when compared to other countries with well-developed special education services" (p. 274). In 2005, Law 5385 emphasized the importance of not only education, but also the social and daily life of special needs students. In 2006, Special Education Services Regulation was reorganized and private special education institutions were taken from Ministry of Family and Social Policies and connected to the Ministry of National Education (Akçamete, 2016). Finally, in 2009 and in 2012 the law 5378 made improvements on special education. New born baby, early childhood and every period of childhood were located constitution for the first time. Moreover, this law mentioned monitoring of physical, auditory, sensory, social, spiritual, and mental development. Ministry of health became responsible for early detection of genetic diseases.

\section{CONCLUSION}

The development of education for exceptional students has a long history in Turkey. In the days of the Ottoman Empire, people with disabilities were considered, but specifically, gifted students because of their unique characteristics. Many hospitals such as Darussifahane were opened to provide what people with disabilities need such as food and treatments for people with disabilities. As Ottomans' Sultans were educated in terms of the Islamic thought, which stressed helping people is important, they came to realize that their weak, poor, and ill people were their responsibility. On the other hand, Enderun School was opened for a specific purpose, to educate gifted people to ensure the existence of Turkey. The development of special education took approximately four hundred years.

In modern Turkey, there were many attempts to provide special education services for children with disabilities. Some were successful while others were not. This was especially true in 2000s when there were significant attempts to improve special education. Such efforts were opening new special education schools, implementing inclusive education, and developing special education programs to develop special educators in the universities. Today, twenty-five state universities and seven private universities have special education programs as they prepare pre-service special education teachers.

Two major problems remain in Turkey in terms of special education implementation. The first issue is the shortage of special education teachers to educate students with special needs. Even though 
there are 25 universities to prepare teachers for special education, these are short term certification programs for teachers outside of special education field (Ozyurek, 2008). These short-term certificate programs could not adequately create well equipped teachers. The second problem is the inclusion of students with special needs in the basic education classroom. There are major shortcomings in teachers' applications about integration and inclusive education (Sarı, 2003) which still need to be addressed. Perhaps as the history continues to unfold, universities can partner with schools to explore the best ways to implement these ideas.

\section{References}

Akçamete, G. (Ed.). (2016). Genel Eğitim Okullarında Özel Eğitim Gereksinimi Olan Öğrenciler ve Özel Eğitim. Ankara: Kök Yayıncılık.

Akkok, F. (2000). Special education research: A Turkish perspective. Exceptionality, 8(4), 273-279.

Cavkaytar, A. (2006). Teacher Training on Special Education in Turkey.Turkish Online Journal of Educational Technology-TOJET, 5(3), 41-45.

Corlu, M. S., Burlbaw, L. M., Capraro, R. M., Corlu, M. A., \& Han, S., (2010). The Ottoman Palace School Enderun and the Man with Multiple Talents, Matrakci Nasuh. Journal of the Korea Society of Mathematical Education Series D: Research in Mathematical Education. 14(1). 19-31.

Erer, S., \& Atici, E., (2010). Selcuklu ve Osmanlilarda Muzikle Tedavi Yapilan Hastaneler. Uludag Universitesi Tip Fakultesi Dergisi. 36(1), 29-32.

Eres, F. (2010). Special education in Turkey. US-China Education Review, 7(4), 94-100.

Eris, B., Seyfi, R., \& Hanoz, S., (2009). Perceptions of Parents with Gifted Children about Gifted Education in Turkey. Gifted and Talented International. 23(2), December, 2008; and 24(1), August, 2009.

Girgin, M. C. (2006). History of higher education provision for the deaf in Turkey and current applications at the Anadolu University. Turkish online Journal of Educational Technology-TOJET, 5(3), 6-11.

Melekoglu, M. A., Cakiroglu, O., \& Malmgren, K. W. (2009). Special education in Turkey. International Journal of Inclusive Education, 13(3), 287-298.

Özyürek, M. (2008). Nitelikli öğretmen yetiştirmede sorunlar ve çözümler: Özel eğitim örneği. Türk Eğitim Bilimleri Dergisi, 6(2), 189-226.

Sabancı, O., Sarıcı Bulut, S., \& Dağlıoğlu, H. E., (2017). Gifted education program in Enderun system. Journal for the Education of Gifted Young Scientists, 5(3), 49-69.

Sahbaz, U. (2018). Özel Eğitim ve Kaynaştırma. Ankara: Anı Yayıncılık

Sarı, H. (2003). Özel eğitime muhtaç öğrencilerin eğitimleriyle ilgili çağdaş öneriler. Ankara: Pegem Yayıncılık.

Subasioglu, F. (2001). Access to information by people with visual impairments in Turkey. Journal of Visual Impairment \& Blindness, 366-368.

Senel, H. G. (1998). Special education in Turkey. European journal of special needs education, 13(3), 254261.

Sengul, E., (2008). Kultur Tarihi icinde Muzikle Tedavi ve Edirne Sultan II. Bayezid Darussifasi. Online Submission. Yok tez arama.

Sezer, F. (2011). Öfke ve Psikolojik Belirtiler Üzerine Müziğin Etkisi. Uluslararası insan Bilimleri Dergisi. 8(1). 1472-1493.

Sirin, M. R., Kulaksizoglu, A., \& Bilgili, A. E. (2004). Üstün yetenekliler. Üstün Yetenekli Çocuklar Seçilmiş Makaleler Kitabı. Istanbul: Çocuk Vakfı Yayınları.

TUik. (2018). Nufus ve Demografi, (www.tuik.gov.tr)

Tuzder (2019). Tum Ustun Zekalilar Dernegi. Dahilerin Okulu "Enderun." Retrieved from http://www.tuzder.org/dhilerin_okulu_enderun_-653_tr_cd.html 